\title{
Contextualizing Indian Masters of Public Health (MPH) programs - challenges and the way forward
}

\author{
Kavya Sharma ${ }^{1}$, Sanjay Zodpey ${ }^{2}$, Himanshu Negandhi ${ }^{3}$, Alison Morgan ${ }^{4}$
}

\begin{abstract}
Introduction: Traditionally, public health education in India is offered through Departments of Community Medicine in medical colleges open only for medical graduates. Against the background of manpower shortages in public health professions, several programs aimed at increasing numbers in specific areas of public health have been initiated recently for medical and non-medical graduates. MPH programs have been introduced for over two decades in the country, however, to date no systematic effort has been undertaken to synthesize all the information related to these courses.
\end{abstract}

Objective: To critically examine and understand the evolution and current status of MPH programs in India and to undertake a curriculum scan of the existing programs.

Methods: Information on Indian institutes offering MPH programs was collected using multiple approaches. The list was prepared by collating information from various sources. The institutes were contacted for procuring information related to MPH programs using a detailed structured questionnaire and the data was assembled in a matrix for further analysis.

Results: Twenty three institutes offering two year MPH programs were identified. Most offer a general MPH with a focus on core areas of public health. However, some of the institutions offer MPH with specialization (social epidemiology, health services management, environmental health, field epidemiology etc.) The course curriculum, eligibility criteria, structure of the program and evaluation system varies across the 23 institutes. A total of 16 batches (including 2010) have produced 1544 MPH graduates till 2010.

Conclusion: The absence of competency frameworks for the MPH courses in India and absence of a central accrediting body need to be urgently addressed. These will lead towards the gradual establishment of career pathways for these graduates in the public health system. The MPH programs also need to be standardized across the country with a uniform curriculum.

\section{Introduction}

Human resources are the central component of all health systems and consume a major share of resources allocated to health systems.

\footnotetext{
${ }^{1}$ Manager, Academic Programs, Public Health Foundation of India

${ }^{2}$ Director, Public Health Education, Public Health Foundation of India

${ }^{3}$ Assistant Professor, Indian Institute of Public Health Delhi, Public Health Foundation of India

${ }^{4}$ Senior Technical Advisor in Maternal Health, Nossal Institute for Global Health, University of Melbourne

Corresponding author:

Prof Sanjay Zodpey

Director of Public Health Education

Public Health Foundation of India, ISID campus, Plot

No.4, Institutional Area, Vasant Kunj, New Delhi- 110070

E-mail: sanjay.zodpey@phfi.org
}

However, shortage of $\mathrm{HRH}$ remains a universal problem in developing countries.

The Master of Public Health (MPH) course is useful in creating public health professionals who can assume wider public health responsibilities at different levels of the health care system.

The establishment of the All India Institute of Hygiene and Public Health (AllH\&PH) Kolkata in December 1932, the oldest school of public health in South-East Asia (AllHPH, 2010) was a welcome development towards imparting public health education in the country. Formal education in public health was gradually introduced in other medical colleges as a subject for undergraduate and postgraduate study. Departments of Preventive and Social Medicine were 
established throughout the country on the recommendations at a Medical Education Conference in 1955 (Thakur et al., 2001). Currently, the Departments of Preventive and Social Medicine (also known as Community Medicine in some medical colleges) are present in every medical college, and are entrusted with the task of orienting medical students towards the basic tenets of public health activities. Medical colleges also offer post graduate programs: MD Preventive and Social Medicine, MD Community Medicine, Diploma in Community Medicine and Diploma in Public Health. A total of 184 medical colleges offer MD programs with an annual output of 602 postgraduates (Medical Council of India, 2011). Thirty-nine medical colleges in India run a Diploma in Public Health program with an annual output of 140 diploma holders and six medical colleges offer a Diploma in Community Medicine to 13 candidates per year. However, these numbers are inadequate to cater to all the needs for public health professionals across the country.

Like all developing countries, India is grappling with manpower shortages among public health professionals. The numerical inadequacy in public health professionals across the country is a matter of debate at academic, policy formulation and implantation circles. While several programs aimed at increasing numbers in specific areas of public health have been initiated in recent years for medical and non-medical graduates, including hospital administration, health management and occupational health; (Zodpey et al., 2009; Sharma \& Zodpey, 2010; Sharma \& Zodpey, 2011a; Sharma \& Zodpey, 2011b) these programs have been designed to develop skills only within a specialist domain. This transition has also created opportunities for interested candidates from a non-medical background (allied health professionals, physiotherapists, occupational therapists, dentists, nursing professionals, social scientists, management professionals, health economists, law graduates and basic science graduates) to study public health.

In the absence of a central regulatory council, there is little standardization across these courses. The MPH programs have been introduced over the last two decades, however, to date no systematic effort has been undertaken to synthesize all the information related to these courses. We therefore undertook this exercise with the objectives of examining the evolution and current status of
MPH programs in India and to undertake a curriculum scan of the existing programs.

\section{Methods}

A systematic and pre-defined approach was used to collect the information for the different courses provided by institutes all over India. Information about Indian institutes offering MPH programs was collected from the World Wide Web and from academic publications and institutional affiliations of the authors publishing in Indian public health journals. Information about other institutes offering similar programs was sought through personal communication with faculty and students using a snowballing approach till no new names surfaced. The details were collected and compiled in the form of a matrix.

The information available in the public domain was searched using the Google search engine. Key words included 'Public health courses in India', 'Master of Public Health' and 'MPH'. The search results were electronically sorted and the results were limited only to courses offered in institutes in India. The websites of the Ministry of Health and Family Welfare (MoHFW) - Government of India and Medical Council of India (MCl) were also searched using the key words of the identified subjects and training programs. A similar search was conducted through the websites of the All India Council of Technical Education (AICTE), the University Grants Commission (UGC) and the Indira Gandhi National Open University (IGNOU). Detailed information about the courses was collected from the respective institutions or from the designated websites of these institutions. Electronic copies of the Education Supplements section of leading national dailies were searched over a period of one year, to look for information regarding the available institutes, courses and their admission criteria.

After obtaining the list of institutions and their contact details, the detailed information about the MPH program covering the number of sanctioned and filled seats, their curriculum, fees, pedagogy, exposure to research and evaluation systems was sought from the department/ school offering the program via email and through telephonic follow-up.

A structured questionnaire was designed for collecting the detailed information from the various institutes identified as providing the MPH courses in India. The questions included information on the type of institute, whether 
government or privately owned, year of establishment and start of the MPH program, number of batches graduated, annual intake and actual candidates enrolled every year, tuition fee, teaching methods, career options and past placements of their alumni. The respondents included senior faculty and administrative heads of the institutes. Any queries related to the tool were answered via email. The data was compiled and collated in a matrix in MS Excel by the research team. The data was simultaneously entered by two independent research associates for data quality check. The institutional data was entered and the findings were triangulated wherever possible. The information procured was cross checked with that available on the respective institute's website. Any mismatch was corrected by contacting the respective institutes. Other salient features of relevance to the courses were also incorporated subjectively in this matrix.

\section{Results}

Twenty three institutes were identified as offering MPH programs in India. The details of these institutes are given in Tables $1 \& 2$. The geographical spread is depicted in Figure 1.

Table 1: Institutes offering MPH programs in India

\begin{tabular}{|c|c|c|c|c|c|c|}
\hline ¿ & Name of the Institute & University affiliation & 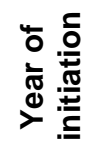 & 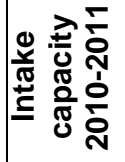 & 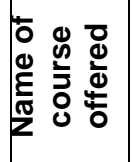 & $\begin{array}{l}\text { Specialized } \\
\text { track (if any) }\end{array}$ \\
\hline 1 & $\begin{array}{l}\text { Achutha Menon Centre for } \\
\text { Health Science Studies, Sree } \\
\text { Chitra Tirunal Institute for } \\
\text { Medical Science and } \\
\text { Technology, } \\
\text { Thiruvananthapuram, Kerala }\end{array}$ & $\begin{array}{l}\text { Sree Chitra Tirunal Institute } \\
\text { of Medical Sciences, } \\
\text { Trivandrum, Kerela }\end{array}$ & 1997 & 15 & MPH & None \\
\hline 2 & $\begin{array}{l}\text { All India Institute of Hygiene \& } \\
\text { Public Health, Kolkata, West } \\
\text { Bengal }\end{array}$ & $\begin{array}{l}\text { West Bengal University of } \\
\text { Health Sciences }\end{array}$ & 2010 & 20 & MPH & Epidemiology \\
\hline 3 & $\begin{array}{l}\text { Asian Institute of Public Health, } \\
\text { Bhubaneswar, Orissa }\end{array}$ & $\begin{array}{l}\text { Ravenshaw University of } \\
\text { Cuttack }\end{array}$ & 2010 & 30 & MPH & None \\
\hline 4 & $\begin{array}{l}\text { Birla Institute of Technology \& } \\
\text { Sciences, Pilani, Rajasthan }\end{array}$ & $\begin{array}{l}\text { Deemed-to-be university } \\
\text { established vide Sec } 3 \text { of } \\
\text { the UGC Act } 1956 .\end{array}$ & 2007 & 20 & $\mathrm{MPH}$ & None \\
\hline 5 & $\begin{array}{l}\text { Centre for Emerging Areas in } \\
\text { Science \& Technology, Punjab } \\
\text { University, Chandigarh, Punjab }\end{array}$ & Punjab University, Punjab & 2007 & 24 & $\mathrm{MPH}$ & None \\
\hline 6 & $\begin{array}{l}\text { Centre for Social Medicine and } \\
\text { Community Health, Jawaharlal } \\
\text { Nehru University, Delhi }\end{array}$ & $\begin{array}{l}\text { Jawaharlal Nehru } \\
\text { University, Delhi }\end{array}$ & 2006 & 8 & MPH & None \\
\hline 7 & $\begin{array}{l}\text { Christian Medical College, } \\
\text { Vellore, Tamil Nadu }\end{array}$ & $\begin{array}{l}\text { Sree Chitra Tirunal Institute } \\
\text { of Medical Sciences, } \\
\text { Trivandrum, Kerela }\end{array}$ & 2009 & 15 & MPH & $\begin{array}{l}\text { International } \\
\text { Health }\end{array}$ \\
\hline 8 & $\begin{array}{l}\text { Datta Meghe Institute of Medical } \\
\text { Sciences, Wardha, Maharashtra }\end{array}$ & $\begin{array}{l}\text { Dutta Meghe Institute of } \\
\text { Medical Sciences (Deemed } \\
\text { University), Maharashtra }\end{array}$ & 2007 & 10 & $\mathrm{MPH}$ & None \\
\hline 9 & $\begin{array}{l}\text { Department of Public Health, } \\
\text { Manipal University, Manipal, } \\
\text { Karnataka }\end{array}$ & $\begin{array}{l}\text { Manipal University, } \\
\text { Manipal, Karnataka }\end{array}$ & 2009 & 18 & $\mathrm{MPH}$ & Epidemiology \\
\hline 10 & $\begin{array}{l}\text { Dr. Giri Lal Gupta institute of } \\
\text { Public Health, University of } \\
\text { Lucknow, Uttar Pradesh }\end{array}$ & $\begin{array}{l}\text { University of Lucknow, } \\
\text { Uttar Pradesh }\end{array}$ & 2008 & 60 & MPH & \\
\hline
\end{tabular}




\begin{tabular}{|c|c|c|c|c|c|c|}
\hline$\frac{1}{0}$ & Name of the Institute & University affiliation & 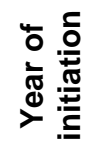 & 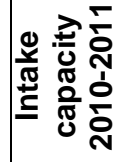 & 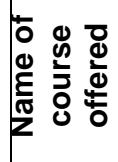 & $\begin{array}{l}\text { Specialized } \\
\text { track (if any) }\end{array}$ \\
\hline 11 & $\begin{array}{l}\text { Interdisciplinary School of } \\
\text { Health Sciences Pune, } \\
\text { Maharashtra }\end{array}$ & $\begin{array}{l}\text { University of Pune, } \\
\text { Maharashtra }\end{array}$ & 2006 & 10 & MPH & $\begin{array}{c}\text { MPH-General } \\
\text { MPH- Maternal } \\
\text { and Child } \\
\text { Health } \\
\text { Specialization } \\
\text { MPH- } \\
\text { Community } \\
\text { Nutrition }\end{array}$ \\
\hline 12 & $\begin{array}{l}\text { J S S University, Mysore, } \\
\text { Karnataka }\end{array}$ & $\begin{array}{l}\text { JSS University, Mysore, } \\
\text { Karnataka }\end{array}$ & 2010 & 20 & $\mathrm{MPH}$ & None \\
\hline 13 & $\begin{array}{l}\text { Jodhpur School of Public Health, } \\
\text { Jodhpur National University, } \\
\text { Jodhpur, Rajasthan }\end{array}$ & $\begin{array}{l}\text { Jodhpur National } \\
\text { University, Jodhpur, } \\
\text { Rajasthan } \\
\end{array}$ & 2008 & 60 & $\mathrm{MPH}$ & None \\
\hline 14 & $\begin{array}{l}\text { KLE University, Belgaum, } \\
\text { Karnataka }\end{array}$ & $\begin{array}{l}\text { KLE University, Belgaum, } \\
\text { Karnataka }\end{array}$ & 2007 & 25 & MPH & None \\
\hline 15 & $\begin{array}{l}\text { National Institute of } \\
\text { Communicable Diseases, New } \\
\text { Delhi }\end{array}$ & $\begin{array}{l}\text { Guru Gobind Singh } \\
\text { Indraprastha University, } \\
\text { New Delhi }\end{array}$ & 2005 & 20 & MPH & $\begin{array}{c}\text { Field } \\
\text { Epidemiology }\end{array}$ \\
\hline 16 & $\begin{array}{l}\text { National Institute of } \\
\text { Epidemiology, Chennai, Tamil } \\
\text { Nadu }\end{array}$ & $\begin{array}{l}\text { Sree Chitra Tirunal Institute } \\
\text { of Medical Sciences, } \\
\text { Trivandrum, Kerela }\end{array}$ & 2008 & 15 & $\mathrm{MPH}$ & $\begin{array}{c}\text { Health Services } \\
\text { Development } \\
\text { and Research }\end{array}$ \\
\hline 17 & $\begin{array}{l}\text { Padmashree School of Public } \\
\text { Health, Bengaluru, Karnataka }\end{array}$ & $\begin{array}{l}\text { Rajiv Gandhi University of } \\
\text { Health Sciences, } \\
\text { Karnataka }\end{array}$ & 2009 & 30 & $\mathrm{MPH}$ & None \\
\hline 18 & $\begin{array}{l}\text { Postgraduate Institute of } \\
\text { Medical Education and } \\
\text { Research, Chandigarh }\end{array}$ & $\begin{array}{l}\text { Post Graduate Institute of } \\
\text { Medical Education and } \\
\text { Research, authorized by } \\
\text { an Act of Parliament to } \\
\text { award degrees }\end{array}$ & 2007 & 18 & MPH & None \\
\hline 19 & $\begin{array}{l}\text { Sam Higginbotom Institute of } \\
\text { Agriculture \& Technology, } \\
\text { (Deemed University), Allahabad } \\
\text { University, Uttar Pradesh }\end{array}$ & $\begin{array}{l}\text { Deemed to be University } \\
\text { formerly AAI-DU, } \\
\text { Allahabad }\end{array}$ & 2000 & 40 & $\mathrm{MPH}$ & $\begin{array}{c}\text { Program } \\
\text { Design and } \\
\text { Management } \\
\text { Reproductive } \\
\text { Health } \\
\text { Training and } \\
\text { Communication } \\
\text { Health system } \\
\text { management } \\
\text { Community } \\
\text { Dentistry } \\
\end{array}$ \\
\hline 20 & $\begin{array}{l}\text { School of Medical Education, } \\
\text { Mahatma Gandhi University, } \\
\text { Kottayam, Kerala }\end{array}$ & $\begin{array}{l}\text { Mahatama Gandhi } \\
\text { University, Kottayam, } \\
\text { Kerela }\end{array}$ & 1995 & 20 & MPH & \\
\hline 21 & $\begin{array}{l}\text { Sri Ramachandra University, } \\
\text { Chennai, Tamil Nadu }\end{array}$ & $\begin{array}{l}\text { Sri Ramachandra } \\
\text { University, Chennai, Tamil } \\
\text { Nadu }\end{array}$ & 2010 & 10 & MPH & $\begin{array}{l}\text { Occupational } \\
\text { and } \\
\text { Environmental } \\
\text { Health }\end{array}$ \\
\hline 22 & $\begin{array}{l}\text { SRM University, Chennai, Tamil } \\
\text { Nadu }\end{array}$ & $\begin{array}{l}\text { SRM University, Chennai, } \\
\text { Tamil Nadu }\end{array}$ & 2007 & 40 & MPH & None \\
\hline 23 & $\begin{array}{l}\text { Tata Institute of Social Sciences, } \\
\text { Mumbai, Maharashtra }\end{array}$ & $\begin{array}{l}\text { Tata Institute of Social } \\
\text { Sciences, Deemed } \\
\text { University under UGC, } \\
\text { HRD, GOI }\end{array}$ & 2008 & 45 & MPH & $\begin{array}{l}\text { Social } \\
\text { Epidemiology } \\
\text { Health Policy, } \\
\text { Finance and } \\
\text { Economics }\end{array}$ \\
\hline
\end{tabular}


Table 2: Institutes offering Electives

\begin{tabular}{|c|c|c|}
\hline ¿̊ํํ & Name of the Institute & Electives (institutes offering) \\
\hline 3 & $\begin{array}{l}\text { Asian Institute of Public } \\
\text { Health, Bhubaneswar, } \\
\text { Orissa }\end{array}$ & $\begin{array}{l}\text { Introduction to Public Health informatics Medical Anthropology } \\
\text { Hospital Management } \\
\text { Interventions for lifestyle disorders } \\
\text { Health Education \& Communication } \\
\text { Demography and population science } \\
\text { Biostatistics II - Advanced Course } \\
\text { Epidemiology II - Advanced Course } \\
\text { Good Clinical Practice (GCP) in Clinical Research } \\
\text { Surveillance, Epidemic Preparedness and Response }\end{array}$ \\
\hline 4 & $\begin{array}{l}\text { Birla Institute of Technology } \\
\text { \& Sciences, Pilani, } \\
\text { Rajasthan }\end{array}$ & $\begin{array}{l}\text { Accounting and Finance } \\
\text { Family \& Community Health Measures } \\
\text { Law and Ethics in Public Health } \\
\text { Strategic Management } \\
\text { Telemedicine } \\
\text { Inter-sectoral co-ordination in Health Services } \\
\text { Role of Voluntary bodies/NGOs in Public Health } \\
\text { Research Methodology I } \\
\text { Hospital Operations Management }\end{array}$ \\
\hline 5 & $\begin{array}{l}\text { Centre for Emerging Areas in } \\
\text { Science \& Technology, } \\
\text { Punjab University, } \\
\text { Chandigarh, Punjab }\end{array}$ & $\begin{array}{l}\text { Occupational Health \& Safety Management } \\
\text { Genetics \& Public Healthor Global Health } \\
\text { Health for Special Groups/Populations or } \\
\text { Public Health in India \& World }\end{array}$ \\
\hline 6 & $\begin{array}{l}\text { Centre for Social Medicine } \\
\text { and Community Health, } \\
\text { Jawaharlal Nehru University, } \\
\text { Delhi }\end{array}$ & $\begin{array}{l}\text { Population Problem and Family Planning Programme in India } \\
\text { Communicable Diseases } \\
\text { Nutrition and Maternal and Child Health } \\
\text { Hospital Administration and Medical Care Services in India } \\
\text { Vital Statistics and Health Information System } \\
\text { Health Manpower Planning in India } \\
\text { Health Planning and Health Economics } \\
\text { Community Health Nursing Education and Administration } \\
\text { Rural Health Services } \\
\text { Operational Research \& Systems Analysis in Community Health Research } \\
\text { Workers Health in India }\end{array}$ \\
\hline 11 & $\begin{array}{l}\text { Interdisciplinary School of } \\
\text { Health Sciences Pune, } \\
\text { Maharashtra }\end{array}$ & $\begin{array}{l}\text { Human Development and Health } \\
\text { Plural systems of medicine } \\
\text { Indian Society } \\
\text { Advanced Epidemiology }\end{array}$ \\
\hline 12 & $\begin{array}{l}\text { J S S University, Mysore, } \\
\text { Karnataka }\end{array}$ & $\begin{array}{l}\text { Dental Public Health } \\
\text { Health Behavior and Sociology }\end{array}$ \\
\hline 13 & $\begin{array}{l}\text { Jodhpur School of Public } \\
\text { Health, Jodhpur National } \\
\text { University, Jodhpur, } \\
\text { Rajasthan }\end{array}$ & $\begin{array}{l}\text { International health } \\
\text { Public health laws } \\
\text { Health policy } \\
\text { Communicable diseases } \\
\text { Non communicable diseases } \\
\text { Maternal and child health }\end{array}$ \\
\hline 14 & $\begin{array}{l}\text { KLE University, Belgaum, } \\
\text { Karnataka }\end{array}$ & $\begin{array}{l}\text { Dental Public Health } \\
\text { Social Science Behavior\& Health Education }\end{array}$ \\
\hline 16 & $\begin{array}{l}\text { National Institute of } \\
\text { Epidemiology, Chennai, } \\
\text { Tamil Nadu }\end{array}$ & $\begin{array}{l}\text { PH aspects of TB at Tuberculosis Research Centre, Chennai } \\
\text { PH aspects of HIV/AIDS at National AIDS Research Institute, Pune } \\
\text { District and national health planning at AlIMS, New Delhi } \\
\text { NRHM at NIHFW, Delhi } \\
\text { Vector-borne diseases at Vector Control Research Centre, Pondicherry, } \\
\text { National Institute of Malaria Research, Chennai and Centre for Research in } \\
\text { Medical Entomology at Madurai } \\
\text { Mental health at SCARF and TTK foundation, Chennai } \\
\text { Health systems with Health systems development project, Govt. of Tamil } \\
\text { Nadu }\end{array}$ \\
\hline
\end{tabular}




\begin{tabular}{|c|c|c|}
\hline 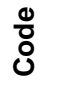 & Name of the Institute & Electives (institutes offering) \\
\hline 18 & $\begin{array}{l}\text { Postgraduate Institute of } \\
\text { Medical Education and } \\
\text { Research, Chandigarh }\end{array}$ & $\begin{array}{l}\text { Health Policy } \\
\text { International Health } \\
\text { Maternal and Child Health } \\
\text { Community Nutrition } \\
\text { Reproductive Health } \\
\text { Public Health Laws and Ethics } \\
\text { Gender and Health } \\
\text { Health Technology } \\
\text { Disaster Preparedness } \\
\text { Pharmaco-economics } \\
\text { Mental Health } \\
\text { Geriatric Health } \\
\text { Communicable Disease Control } \\
\text { Non Communicable Diseases } \\
\text { Community-based Rehabilitation } \\
\text { Accelerated Changes in Life Style } \\
\text { Other Medical Systems }\end{array}$ \\
\hline 22 & $\begin{array}{l}\text { SRM University, Chennai, } \\
\text { Tamil Nadu }\end{array}$ & $\begin{array}{l}\text { Information Technology in Health care } \\
\text { Public Health Program management } \\
\text { Clinical Research } \\
\text { Industrial and Occupational health (only for medical students) }\end{array}$ \\
\hline
\end{tabular}

Figure 1: Geographical distribution of MPH programs in India

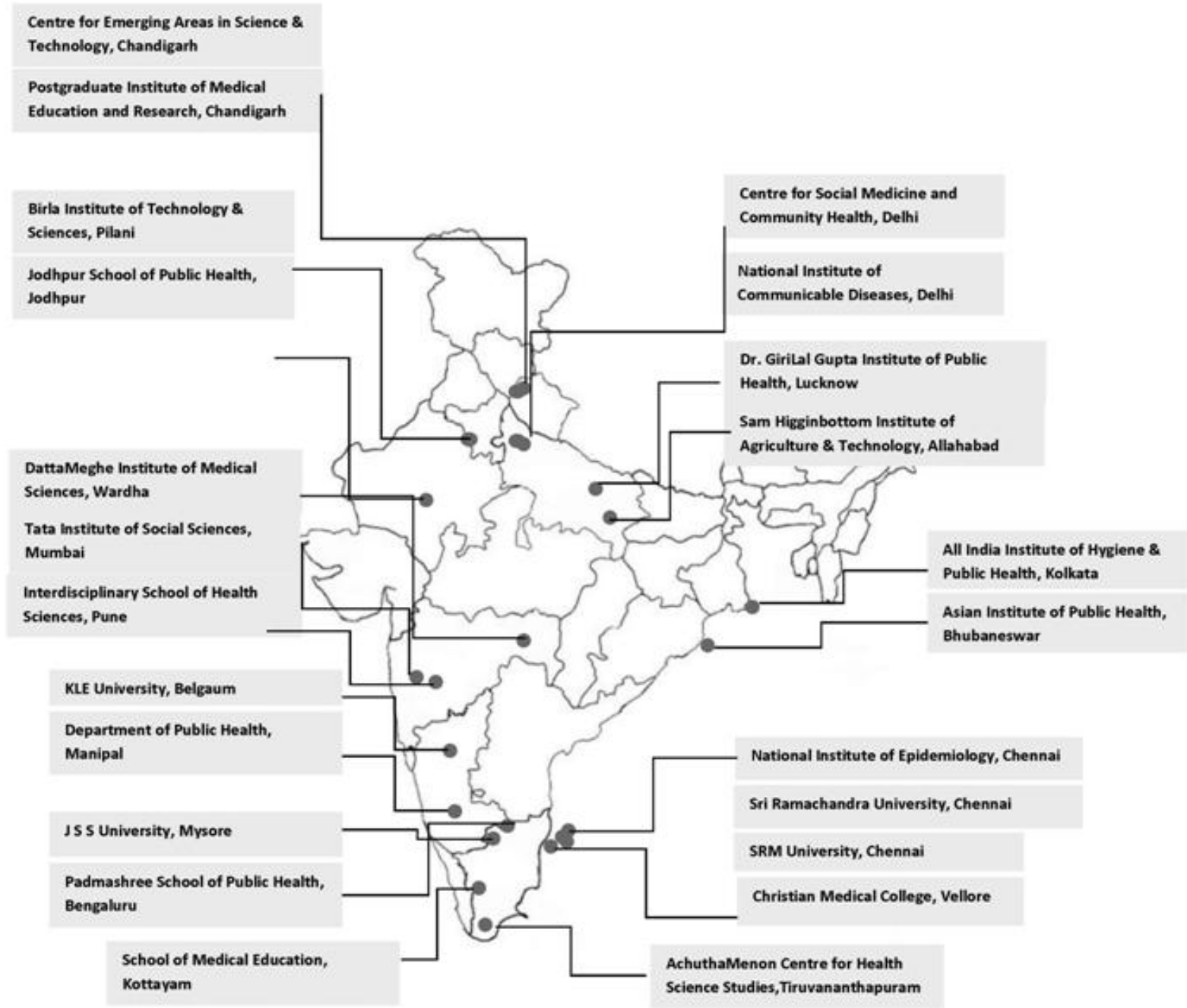


These 23 institutes offer a full time, two years Master of Public Health (MPH) program in India. The programs have a university affiliation under the University Grants Commission (UGC) Act. The UGC is the statutory body of the Government of India through an Act of Parliament for the coordination, determination and maintenance of standards of university education in India. Three institutes (Achutha Menon Centre for Health Science Studies, Trivandrum, Christian Medical College, Vellore and the National Institute of Epidemiology, Chennai) offer an MPH which is recognized by the Sree Chitra Tirunal Institute of Medical Sciences, /Trivandrum, which is established by an act of the Indian Parliament and has the status of a university.

Of these 23 institutes, eight institutes are Government run, being supported by the Central or the State governments, while 15 institutions are privately run. In addition to these 23 institutes currently offering MPH programs, an Executive Program in Health and Population for Developing Countries (MPH/ MHA) was offered by IIHMR-Jaipur. This program was however discontinued after running for five academic years (1992-93 to 1997-98).
The first MPH program commenced in 1995, by the School of Medical Education, Mahatma Gandhi University - Kottayam Kerala with a batch of 20 students. The Achutha Menon Centre for Health Science Studies, Sree Chitra Tirunal Institute for Medical Sciences and Technology - Trivandrum started its MPH program in 1997 with a batch of 15 students. Allahabad University started off with their MPH program in the year 2000 from the Christian School of Health Sciences, Faculty of Health Medical Sciences, Indigenous \& Alternative system of Medicine under Sam Higginbottom Institute of Agriculture, Technology and Sciences, (Deemed to be University, formerly AAI-DU), Allahabad. In 2005, National Institute of Communicable Diseases, New Delhi (now known as National Centre for Disease Control, NCDC) started their MPH program in Field Epidemiology. The evolution of MPH programs saw a rapid spurt with many institutes offering programs from the 2006-07 academic year.

A total of 16 batches (including 2010) have undergone this program, producing $1544 \mathrm{MPH}$ graduates till 2010. The total intake of the MPH professionals for the year 2010 was 573, with 430 candidates enrolling for these programs. Figure 2 represents the year wide distribution of number of seats offered and candidates enrolled for the MPH program.

Figure 2: Year wise distribution of seats available and candidates enrolled

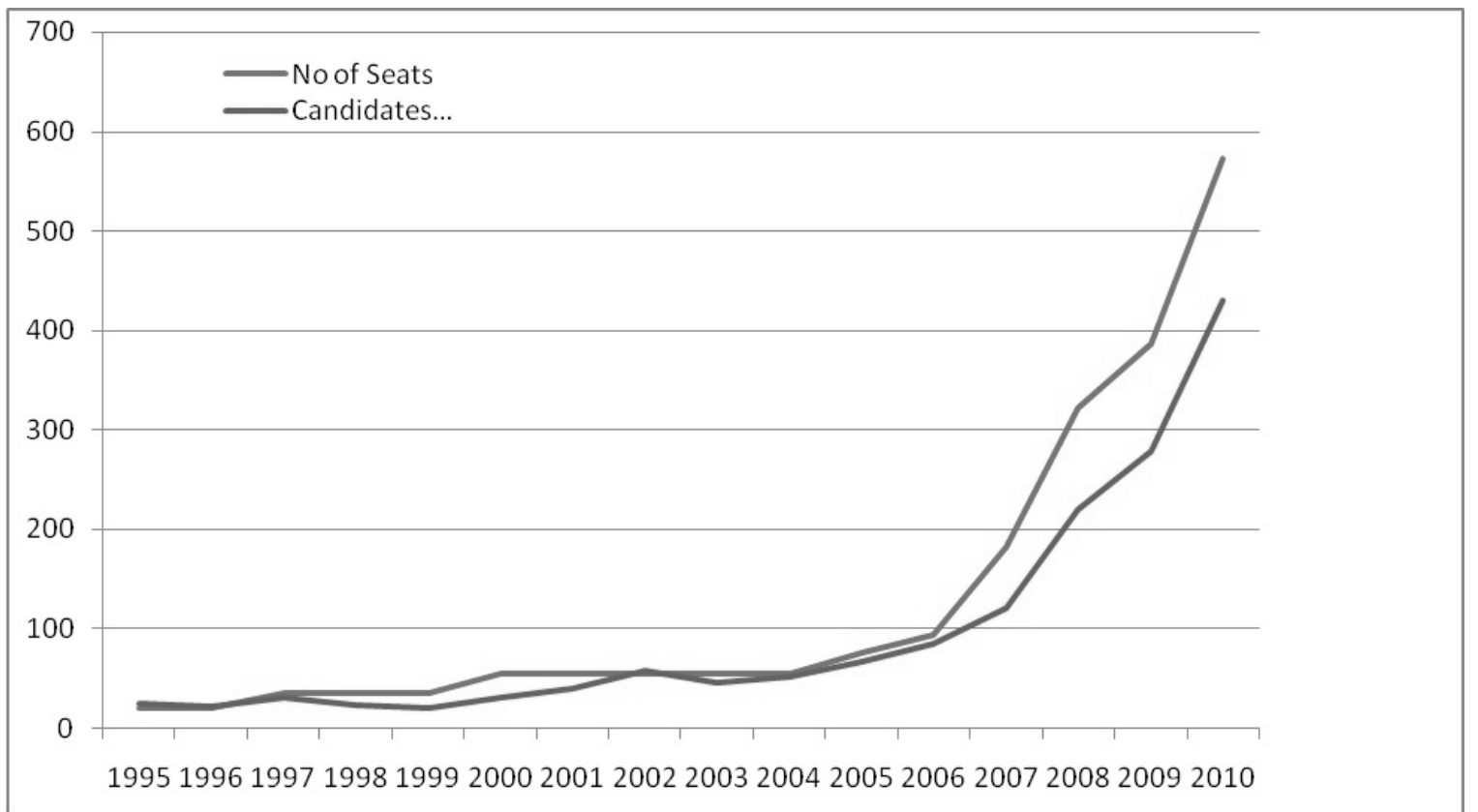


The fee structure is variable in all the twenty three institutes, with tuition fees for the entire program ranging from as low as INR 240 in Government supported institutes to as high INR 400,000 in some of the private institutes. This tuition fee covers only academic fees and excludes fees paid for hostel accommodation, expenses incurred on food etc.

The institutes follow either semester or yearly pattern for the entire course duration of two years. The eligibility criteria for the programs vary between the institutions. Broadly, the courses are open to both medical and nonmedical graduates. The syllabus shows wide heterogeneity across the programs. Most institutions offer a general MPH with a focus on core areas of public health while some offer $\mathrm{MPH}$ with specialization. In addition to core modules and specialization, some institutes also offer electives in specific areas of public health (Table 2).

The various teaching methodology adapted in these institutes include classroom teaching, PowerPoint presentations, field visits, project work, seminars etc. Other teaching methodologies include practical assignments, practical according to the electives, interactive learning by class room discussions and various guest lectures, summer internship, and final dissertation work submission. The dissertation areas include: public defence, extensive field to lab based training approach, training-health communication. Some institutes also send their students for primary health centre postings, visits to institutions/ organizations of public health importance, promote e-learning, and organize case-based learning, problem-based learning, and selfdirected learning. The guest lectures are usually delivered by District Program Officers. There is also a focus on real time field investigation, group discussion, case study and hands on experience.

The evaluation system is variable across all the twenty-three institutes. It is either based upon term examinations or semester examinations. The broad areas of assessment cover theory, practicum, internal assessments and project work. There are class room tests or concurrent evaluations to update upon the daily progress in some institutes. Dissertation and project work carries a major percentage share of the overall assessment. The students are expected to submit a detailed report at the end of their internships and are assessed on it. A viva voce and practical exam are also conducted.
The graduates with a medical background have opportunities to work with Government institutions and health services after completion of this program. While the nonmedical graduates do not currently have multiple opportunities of this kind, additional options like the NGO sector, developmental partners and International organizations are available for both medical and non-medical graduates. Limited opportunities are also available now in the pharmaceutical industry and the Information technology industry.

\section{Discussion}

This exercise was one of the first attempts to systematically map the existing scenario of public health education being offered as a Master's program in India. There was no such comparative analysis available. Though a substantial number of seats are available for Master of Public Health, a limited number of students opt for such programs. Apart from meeting the large shortfall in availability of public health professionals, at several levels, the knowledge and skills of these professionals and functionaries have to be appropriately and designed to ensure delivery of public health services at the desired quality and scale. The issue of low demand for MPH courses in the presence of a felt need can be attributed to a lack of clarity about career pathways and job opportunities for the MPH graduates.

Competency frameworks for MPH courses are currently not developed in India. The courses are an adaptation of the programs offered by reputed institutes in the West. In the presence of this discordance about the context of the program, the content needs to be suitably contextualized to India. Efforts should be underway towards the development of competency frameworks for these courses. The competencies that need to be acquired at the completion of the course need to be defined at the country level by identifying the core skills to be acquired and applied by the graduates at their workplace. The elements under these core skills should be delineated and a choice must be made about the pedagogic methods to be used in order to develop these skills. Developing a framework of competencies for MPH programs in India is an iterative process. The need and demands of the public health system are dynamic and to meet these ever-changing needs, public health competencies must be redefined appropriately. India can adopt a strategy to periodically review public health 
competencies. Developing a national public health performance standard program to improve the practice of public health in India would be useful in this regard. Once there is a competency framework in place, there can be efforts by individual schools to evaluate their existing programs to determine the extent each competency is addressed by each course (Loos, 1995).

The accreditation of these programs is another vexed issue. In the presence of wide variations in the content and the context of the offered programs, it is essential to ensure program accreditation. In the absence of a central regulatory body governing these programs, the primary question is identifying a body that would be able to accredit these programs. The options available to institutions are accreditation by a network of institutions or by a national level university. Some of the suggested accreditation bodies in India can include a network or alliance of institutions like IndiaPHEIn, national bodies such as the DNB, Indian Public Health Association or recognized universities. This accreditation process must engage a variety of stakeholders like representation of teaching institutions, their faculty and students, international agencies and partner universities, professional bodies as well as the Government. The presence of an accreditation system would not only address a felt need within the educational circles, but also aid in student employment. The current environment favours accreditation with an interest from the donor community and a collective global movement towards accreditation. However, the absence of a centrally agreeable body across the country and the multiplicity of stakeholders makes it challenging to design an accreditation system. A mechanism, wherein all the current MPH offering institutions constitute a joint effort to design an accreditation framework could offer a solution.

Career opportunities include all sectors of industry, universities, research organizations, laboratories, governmental agencies and NGOs involved in the areas of environment, occupational health and safety, public health, energy and development. The course contents are also specifically tailored for those seeking to advance their position as environmental health and safety professionals, including occupational physicians, safety officers, EHS managers, factory inspectors and pollution control scientists /engineers and faculty/ research scientists.
The future prospects will depend on the commitment of the Government to make this qualification a requirement for multiple positions within and outside the Government. Currently there is a great deal of misconception regarding the actual job profile of MPH degree holders. In our experience, most employers feel that there is no need for a formal training in this specialty and that these function can easily be performed by available personnel. Employers have limited understanding of the skill set these graduates can bring to organizations and are unwilling to create new positions. Existing relevant positions therefore would need to be preferentially filled with MPH graduates with appropriate specializations. Despite a large number of such professionals being available to serve the public health community, there is a massive dearth in employment opportunities available. There are no set recruitment rules that may open up avenues for non-medical background people to be placed in the public health system. Such openings are only available to medical professionals trained in public health.

MPH graduates can play a role in existing health programs. Limited opportunities are available under these programs that can be effectively filled by these graduates. An example is the Integrated Disease Surveillance Project running throughout the country. According to NRHM/IDSP one Epidemiologist is to be posted in every district of the country. There is acute shortage of epidemiologists in our country. MPH courses include epidemiology as a core skill, with academic and practical understanding of the concepts and their application. Therefore the IDSP program can be looked upon as an opportunity to include MPH (Epidemiology) scholars and their gradual absorption in to the public sector.

Similarly, the position of the Block Programme Manager and the District Programme Manager are managerial positions available under the NRHM. Course modules across most programmes equip participants with the necessary skills. Additionally, the NonGovernmental Organizations are also in need of public health professionals and are potential employers in the private sector for these graduates. Similarly, there is a dire need for occupational health physicians across the country. Graduates from MPH programmes in Occupational and Environmental Health can partly overcome this shortfall. 
The purpose of the Master of Public Health (MPH) program is to train human resources in the science of public health, with a firm understanding of the determinants of health and the public health system in the country, the community context, the determinative influences of globalization, urbanization, global and national policies and a strong foundation in research methodology. But the programs need to connect with the health situation in the county. The mechanisms for this need to be examined and can be structured around field based learning for the relevant modules. The current MPH programs must extend beyond classrooms to reach the field reality. Interdisciplinary learning, which enables public health professionals to identify multiple determinants of health and influence them through multi-sectoral pathways, must be promoted through a fusion of several disciplines which have hitherto been taught in relative isolation. We need to provide for better opportunities for MPH graduates to advance their academic qualifications through doctoral programs. Similarly DrPH programs can provide opportunities for applying the public health skills within communities. Such academic opportunities are not available currently within the Indian academic settings.

The study was successful in contacting all the twenty three institutes that are offering an $\mathrm{MPH}$ program in India. The detailed information was procured from all these institutes, triangulated and then analysed. The findings were also disseminated amongst key stakeholders across the country which also included representations from these institutes. However, the study had certain limitations. The tool used for the purpose of data collection was self-administered, therefore could not be comprehensively verified and triangulated. The study is an overall descriptive analysis of the findings.

\section{Conclusions}

Public health professionals come from varying educational backgrounds and can specialize in an array of fields. A host of specialists, including teachers, journalists, researchers, administrators, environmentalists, social workers, demographers, laboratory scientists, economists, and lawyers, work to protect the health of the public. Public health professionals serve local, national, and international communities. The presence of diverse backgrounds and experiences before enrolling into the MPH program while necessary, brings with it challenges in the course delivery. There is a need to orient these professionals in the current public health systems and the advances in the field through foundation programs. Such specially structured courses may be offered to bring all these candidates to the same level of competence before the actual roll out of the academic modules. Mechanisms for such activities will need to be flexible so as to permit adaptation for differing student composition year after year.

India has a shortage of public health professionals while it faces multiple public health challenges. MPH contribute towards addressing these challenges. For any country to improve their health systems an important component is to facilitate training in public health. MPH programs can provide for emergence of leadership and expertise in the field of public health that can supplement the existing health system.

\section{References}

AllHPH (2010). All India Institute of Hygiene and Public Health [Online] Available at http://www.aiihph.gov.in [Accessed 6th December 2010].

Loos, G. P. (1995). Minimum competencies for public health personnel, Asia Pacific Journal of Public Health, 8, pp.195-200.

Medical Council of India (2011) List of colleges teaching PG courses [Online] Available at http://www.mciindia.org/InformationDesk/ForStu dents/ListofCollegesTeachingPGCourses.aspx [Accessed 8th May 2011].

Sharma, K. \& Zodpey, S. (2010) Need and opportunities for health management education in India, Indian Journal of Public Health, 54, pp. 84-91.

Sharma, K. \& Zodpey, S. (2011a). Demand and supply analysis of human resource capacity in hospital management in India,Journal of Health Management, 2, pp. 155-176.

Sharma, K. \& Zodpey, S. (2011b) Health and hospital management education in India. Journal of Indian Association of Preventive and Social Medicine, Gujarat Chapter, 2, pp. 13-16.

Thakur, H.P., Pandit, D.D. \& Subramanian, P. (2001)History of preventive and social medicine in India, Journal of Postgraduate Medicine, 47, pp. 283-285.

Zodpey, S.P., Negandhi, H. \& Tiwari, R. R. (2009) Mapping 'Occupational Health' courses in India: A systematic review, Indian Journal of Occupational and Environmental Medicine, 13, pp. 135-140. 